\title{
BIOMASSZA-ALAPÚ ENERGIAHASZNOSÍTÁS: A MÚLT ÉS A JÖVŐ
}

\section{BIOMASS-BASED ENERGY UTILIZATION: PAST AND FUTURE}

\author{
Dinya László \\ a mezőgazdasági tudomány kandidátusa, egyetemi tanár, Eszterházy Károly Egyetem Gyöngyösi Károly Róbert Campus \\ Idinya@freemail.hu
}

\begin{abstract}
ÖSSZEFOGLALÁS
A gyorsuló technikai fejlődés, a negyedik ipari forradalom és a digitalizáció („Internet of Things"), valamint a növekvő globális fenntarthatósági kihívások korában az energiagazdálkodás is radikális átalakulás előtt áll. A bioenergetikai ágazatot mindez és emellett még számos további gazdasági-környezeti kihívás is hangsúlyosan érinti. Az egymással is összefonódó trendeket rendszerbe foglaltuk, és ennek alapján megfogalmaztunk számos javaslatot, amelyeket célszerűnek látunk érvényesíteni az eddiginél jóval megalapozottabb beruházási, fejlesztési és támogatási döntések érdekében a bioenergetika területén. Felhívtuk a figyelmet a szakmai szempontokat előtérbe helyező, tágabb rendszerbe illeszkedő, hosszú távú és termékpályákban gondolkodó döntéshozatal fontosságára a helyi és országos szintű döntések során egyaránt. Rámutattunk arra, hogy a biomassza energetikai hasznosítása a jövőben is fontos része lesz az energiamixnek, de a vezető szerep más megújuló forrásokra vár.
\end{abstract}

\section{ABSTRACT}

In the era of accelerating technical developments, the Fourth Industrial Revolution and digitalization (Internet of Things), and in the face of growing global sustainability challenges the energy management is also undergoing radical transformation. The bioenergy sector is all the more affected by these and many other economic and environmental challenges. We included the systemized interlinked trends, and on this basis we have formulated a number of proposals that we consider to be valid for the well-founded investment, development, what support decisions in the field of bioenergy. We have drawn the attention to the importance of more professional, long-term and product-oriented decision-making fitted into a broader system both at local and national level. We have pointed out that the energy utilization of biomass will continue to be an important part of the energy mix in the future, but the leadership role is going to other renewable sources.

Kulcsszavak: bioenergetika, fenntarthatóság, energiagazdálkodás, komplex megközelítés, prioritások

Keywords: bioenergetics, sustainability, energy management, complex approach, priorities 


\section{ÁTRENDEZŐDŐ PRIORITÁSOK}

Az előző évtizedben Magyarországon (is) nagy lendülettel megindult, ígéretesnek tünt bioenergetikai fejlesztések megtorpantak, ezért a formálódó új ágazat helyzetét és főként a jövőjét számos, korábban figyelmen kívül hagyott tényező miatt célszerü újra áttekinteni. Miközben az energiakérdés továbbra is a globális prioritások élén áll, alapvetően új körülményeket jelent viszont számos változás, amelyek közül a legfontosabbak a következők:

- a legtöbb ágazatot (így a bioenergetikát is) új pályára terelő GPT (General Purpose Technology, általános célú, azaz több ágazatot érintő technológiai) jellegű innovációk gyorsuló ütemben történő megjelenése és bevezetése (például az új technológiák radikálisan csökkentik a megújulók beruházási költségeit);

- a technológiák korábbi hatékonyságát nagyságrenddel megnövelő intelligens (smart) alkalmazások és a helyi energiaforrásokat preferáló decentralizált hálózatok terjedése;

- ezekkel is összefüggésben a megújuló energia kapcsán történő beruházások között a nap- és szélenergia dominánssá válása és a bioenergetikai beruházások stagnálása, relatív visszaesése;

- minderre válaszként az EU újabb törekvése a 2020-ig szóló, korábban rögzített bioenergetikai célkitűzések (ún. ,3 × 20\%”) revideálására, azaz csökkentésére;

- az agrobusiness szektor fokozatos átalakulása bioökonómiává (a biomassza maximális hozzáadott értékű termékekké transzformálása);

- a különféle (készülő) globális szabadkereskedelmi megállapodások, illetve az EU-s támogatási rendszer várható átalakulása 2020 után, amelyek radikálisan megváltoztatják az európai és a hazai agrárium (és valamennyi ágazat) müködési feltételeit;

- a nyitott innovációs rendszerek és a vállalati ökoszisztémák (hármas, négyes, ötös spirál elven alapuló innovációs hálózatok) feltünése, amelyekben elválaszthatatlanul összefonódnak az üzleti, a civil és a $\mathrm{K}+\mathrm{F}+\mathrm{I}$-szférák szereplöi a bioenergetikai szektorban is;

- az externális (társadalmi és ökológiai) tényezők fokozatos beépülése az üzleti modellekbe, a különböző szintü (globális, nemzeti, térségi, lokális) fejlesztéspolitikai koncepciókba, döntésekbe, és ennek nyomán a fenntarthatósági paradigmaváltás gyorsulása.

Miután hazánk biomassza-potenciálja a jövőben is az egyik legjelentősebb természeti erőforrásunk marad, ennek fenntartható és optimális hasznosítása a megváltozott feltételek és lehetőségek figyelembevételével alapvetően újszerü, a korábbinál jóval komplexebb megközelítést igényel. A hazai bioenergetikai 
ágazat fejlesztésének összhangban kell lennie a globális és makroszintủ trendekkel, és eközben illeszkednie kell a differenciált lokális (térségi és települési) feltételekhez is. Stratégiai kitekintéssel újra fel kell értékelni a hazai biomaszsza-potenciált (megkülönböztetve az elméleti, konverziós, technikai, gazdasági és fenntartható potenciált, lásd Dinya, 2010), annak jövőbeni alakulását, a gazdasági, társadalmi és környezeti szempontból perspektivikus bioenergetikai technológiákat és termékpályákat (újonnan kidolgozandó, a hazai viszonyokhoz is illeszkedő, komplex kritériumrendszer alapján auditálható módon). Ennek alapján újra kell gondolni a támogatási és szaktanácsadási rendszer át- (illetve ki)alakítását is. Egyidejüleg fel kell készülnünk a helyi energiaforrásokat integráló európai energiahálózat várható megvalósulására (ESSG - European Super Smart Grid, azaz Európai Intelligens Szuperhálózat), amelyben hazánk esetében egyik fontos helyi energiaforrásként éppen a biomasszával kalkulálnak. A biomassza energetikai hasznosításának helyzetét mindenesetre találóan jellemzi egy nagy és viszonylag friss nemzetközi jelentés mottója: „A biomaszsza valószínűleg a legellentmondásosabb és a legkevésbé megértett megújuló energiaforrás" (Paulos, 2017).

Az biztos, hogy a kérdéshez az eddigitől jelentősen eltérö, integrált és komplex szemléletben kell közelíteni, és minden kapcsolódó (technológiai, szervezési, üzleti, társadalmi, szabályozási) terület innovatív megoldásokat igényel. Ehhez szükség van a részben már meglevő globális és makroszintü bioenergetikai tudásbázisunk folyamatos továbbfejlesztésén túl a bioenergetikai vertikum (termékpályák) fenntartható energiagazdálkodásba illesztését célzó, átfogó kutatási feladatok folyamatos végzésére is.

\section{HAZAI HELYZETKÉP}

Célul tủztük ki a lehetséges jövőbeni szcenáriók felmérését, valamint ezek alapján az észszerü hazai fejlesztési irányelvek megfogalmazását. Nem volt célunk ugyanakkor vitázni ,alternatív tényekkel”, jól ismert közhelyekre pazarolni korlátozott időnket, a rációt emócióval pótolni, „hitvitákba” bonyolódni, illetőleg szakpolitikai helyett politikai szempontokat követni...

Kiindulópontnak vettük (József Attilát idézve), hogy ,a törvény a tiszta beszéd", ezért összefoglaljuk, mintegy dióhéjban, hogyan tekintünk (kellene tekintenünk) a biomassza energetikai hasznosítására:

1. Bár hazánk biomassza-potenciálja relatíve (az ország méretéhez képest) jelentős, az sokféle módon és erősen „korlátozott”, többek korábbi nézetével szemben nem vagyunk biomassza-nagyhatalom.

2. A biomasszából nyert energiát sokan „zöldenergiának” becézik, de látnunk kell, hogy nem minden „zöld”, ami „bio” - az igen változatos bioenergetikai 
technológiák jelentős része életciklus-elemzés alapján korántsem környezetbarát.

3. A biomassza kifejezetten energiacélú előállítását nem gondoljuk preferálni, ellenben a biomassza előállításakor (és általában az emberi tevékenység során) keletkező melléktermékek energetikai hasznosítását feltétlenül. Mindig van melléktermék, ami környezetvédelmi, gazdasági és energetikai szempontból egyáltalán nem mellékes.

4. A biomassza (mint nyersanyag) energetikai célú felhasználása komoly ráfordítások nélkül nem lehetséges, ezért a nap- és szélenergiától eltérően inkább tekintendő megújítható, mint megújuló energiaforrásnak.

5. Józan számítások és az egyre világosabban kirajzolódó energetikai trendek alapján egyértelmü, hogy akár hazai, akár globális szinten a biomasszából nyert energia sosem elégítheti ki teljes mértékben az energiaigényt. De belátható távon fontos kiegészítő szerepe lesz, amit nem kiaknázni ,több mint bün - ez hiba" lenne.

6. Egyik ilyen előnye a többi megújuló energiaforrással szemben a „puffer”szerep: tárolható és adagolható, így szabályozhatóbb az energiakinyerés.

7. Szemben a többi megújuló energiaforrással a biomassza mint nyersanyag számtalan formában rendelkezésre áll, de ez esetben a változatosság nem gyönyörködtet, mert bonyolultabbá teszi a technológiákat. Ez nem válik előnyére.

8. Ugyanakkor a biomassza széles körü „,pozitív externáliák” lehetőségével is párosul: munkahelyteremtés, helyi gazdaságfejlesztés, környezetvédelem stb. Ezeket be kell építeni a projektek üzleti modelljeibe, illetve figyelembe kell venni a támogatási rendszer kialakításánál is.

9. A biomasszát, szemben a többi megújulóval, igen bonyolult érdekviszonyok övezik: alternatív hasznosítási módok, verseny a termőföldért, komplex termékpálya - mindez sok szereplőt integrál, azok összehangolása pedig állandó kontrollt és igen rugalmas rendszert igényel.

10. A biomasszát övező kudarcsztorik nagy száma arra utal, hogy a sikeres projektekhez szükséges döntéshozói hozzáértést semelyik szinten sem helyettesítheti a bulvárszintü és hézagos tájékozottság. Különösen nem a parciális érdekek mentén hozott döntések.

A fentieket összefoglalva nyugodtan kijelenthetö, hogy a biomassza másként megújuló, mint a megújulónak nevezett többi energiaforrás. 


\section{GLOBÁLIS HELYZETKÉP}

Amennyiben hazánk nem óhajt szembemenni a globális energetikai trendekkel (minden észszerűség emellett szól), akkor számolni kell a következő tendenciákkal, amelyek a legfrissebb és nagyszámú nemzetközi forrás összevetéséből rajzolódnak ki hosszabb (de belátható) időtávon (Schiffer et al., 2016; International Energy Agency, 2016).

- A következő húsz évben (kb. 2035-ig) a globális reál GDP megduplázódik, a globális népesség 8,8 milliárd főre nő (a jelenleginél 1,5 milliárddal több), és kb. kétmilliárd ember kiemelkedik a szegénységből. Bár az energiahatékonyság is jelentősen növekszik, de az energiaigény összességében 30\%-kal nagyobb lesz.

- A teljes energiaigényt ebben a távlatban elöreláthatólag kb. 30\%-ban lesznek képesek fedezni a megújulók (nap-, szél-, geotermális, víz- és bioenergia, egyéb), illetve 70\%-ban a fosszilis energiaforrások (kőolaj, földgáz, szén, nukleáris, egyéb). Ebből következően az energetikai beruházások legnagyobb hányada várhatóan a nem fosszilis új kapacitásokat célozza meg ( $\mathrm{kb}$. 7\%/év növekedési ütem).

- Az energiaigény növekedése jelentős mértékben az elektromos energiát érinti (automatizálás, digitalizáció) - ennek részaránya a fogyasztásban a jelenlegi 42\%-ról kb. 55\%-ra nő.

A legfrissebb EU-felmérés (Pelkmans, 2016) ezekből is levezethető megállapításokat tartalmaz a bioenergetikai ágazat fejlődését akadályozó tényezők kapcsán:

- a közvélemény/média/politikai döntéshozók elégtelen ismerete, tudása;

- a biomassza rossz imázsa a bioüzemanyagok számos kudarcsztorija miatt;

- tagállamonként eltérö fenntarthatósági követelmények a bioenergetikai technológiákkal szemben;

- tagállamonként eltérő fenntarthatósági politikák az agrárium és az erdőgazdálkodás terén;

- a fosszilis energiahordozók kapcsán hiányzó fenntarthatósági követelmények egyenlőtlen esélyủ versenypályát jelentenek a megújuló energiák számára;

- a gyakran módosuló fenntarthatósági kritériumok kiszámíthatatlanná teszik a bioenergetikai ágazatot a szereplők számára;

- a biomassza alternatív (nem energia célú) hasznosítására nem vonatkoznak fenntarthatósági követelmények;

- kiépítetlen a szállítási (logisztikai) infrastruktúra.

Ennek megfelelően a következő energiapolitikai prioritásokat fogalmazzák meg a biomassza vonatkozásában (fontossági sorrendben): 
(1) Szigorú monitoringgal párosuló erdőgazdálkodás megvalósítása az erdészeti biomassza felhasználásában.

(2) Szoros együttműködés és a jól fenntartható gyakorlatok cseréje a biomaszszát kibocsátó föbb régiók között.

(3) EU-szinten összehangolt fenntarthatósági követelményrendszer bevezetése a biomassza szilárd és gázalapú energetikai hasznosításában.

(4) Nemzetközi szinten összehangolt müszaki normák bevezetése a bioenergetikai technológiák engedélyezésénél és alkalmazásánál.

(5) Minden biomassza-alapú energiahordozó ellátása egyedi azonosítóval, amely igazolja, hogy legális eredetủ és a fenntarthatóságnak megfelelő.

(6) Fenntarthatósági vagy egyéb externális kockázatot jelentő alapanyagok kizárása a támogatott körből.

(7) Jelentős ösztönzők bevezetése a preferált jó gyakorlatokat képviselő technológiák alkalmazásánál, és ezek körének egyértelmü, EU-szintủ meghatározása.

(8) Hatékony és az értéklánc minden elemére kiterjedő monitoringrendszerrel biztosítani a rögzített elvek érvényesítését legkésőbb 2020-ig.

\section{A MEGALAPOZOTT DÖNTÉSEKHEZ FONTOS RENDSZERKAPCSOLATOK FIGYELEMBEVÉTELE}

A bioenergetikai ágazat jövőjével kapcsolatos makroszintü, illetőleg a bioenergetikai projektek megalapozását célzó mikroszintủ döntéseknél számos összefüggés, illetve megközelítési szempont mérlegelése célszerủ (1. ábra).

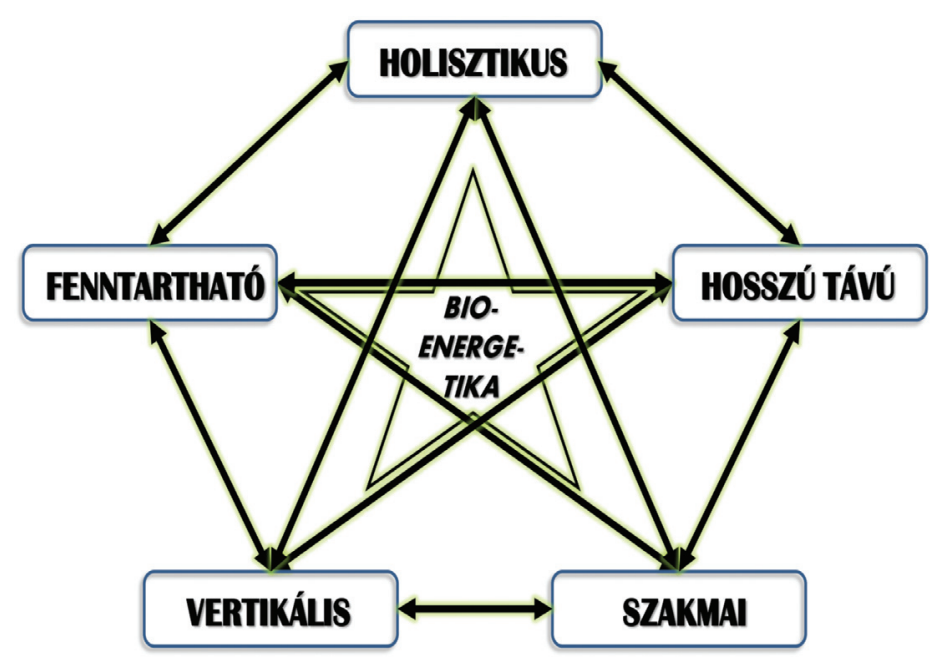

1. ábra. A bioenergetika tágabb kontextusba illesztve (saját szerkesztés) 
Tömören megfogalmazva úgy véljük, hogy a racionális bioenergetikai döntésekhez ennek az öt kritériumcsomagnak az egyidejű teljesülése szükséges. A kapcsolódó mottók sarkítva (és plasztikusan) kívánják illusztrálni a lényegüket, vagy indokolni a fontosságukat. Részletesebben az alábbiakban fejtjük ki a kritériumokat.

\section{Holisztikus szemlélet}

„Világunkat olyan döntéshozók uralják, akiknek az agya még az atomkor előtt megszilárdult.” (Szent-Györgyi Albert, 1986)

Ennek keretében a föbb szempontok:

- Meg kell valósítani a multifaktoros értékelést, anélkül racionális támogatási rendszer vagy projekt a jövőben elképzelhetetlen. Több nemzetközi elemzés szintéziséből az tünik ki, hogy a hét faktor (szempont) szerint értékelt különféle energetikai fejlesztési projektek rangsorának élén a szél- és a napenergia, harmadik helyen a bioenergetikai beruházás áll, míg a nukleáris projekt az utolsó (1. táblázat).

- A fejlesztési projektek klasszikus üzleti modelljeinek át kell adniuk a helyüket az ún. intelligens modelleknek, amelyek alapja az IT (információs technológiák) és az intelligens eszközök mindent átfogó, hálózatba kapcsolt alkalmazása.

1. táblázat. Multifaktoros összehasonlító értékelés fontossága

\begin{tabular}{|c|c|c|c|c|c|c|c|c|c|c|}
\hline Értékelési szempont (1-5) & 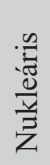 & $\begin{array}{l}\text { त्र } \\
\text { of } \\
0 \\
00 \\
0\end{array}$ & $\begin{array}{l}\text { N } \\
\text { N }\end{array}$ & $\begin{array}{l}\overline{\mathcal{N}} \\
\tilde{n}\end{array}$ & శ్ & $i^{N}$ & 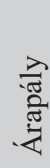 & 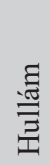 & 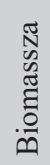 & $\begin{array}{l}\stackrel{\pi}{0} \\
\frac{0}{0} \\
0 \\
0\end{array}$ \\
\hline Gazdaságilag életképes & 1 & 5 & 4 & 5 & 4 & 4 & 2 & 1 & 4 & 2 \\
\hline Alacsony negatív externáliák & 4 & 2 & 1 & 5 & 5 & 3 & 4 & 4 & 3 & 5 \\
\hline Sok helyen telepíthetö & 2 & 4 & 4 & 5 & 5 & 3 & 3 & 3 & 4 & 3 \\
\hline Rugalmas üzemmód & 1 & 5 & 2 & 5 & 5 & 4 & 4 & 4 & 5 & 4 \\
\hline Gyors építés & 1 & 4 & 2 & 5 & 5 & 2 & 4 & 4 & 4 & 2 \\
\hline Megbízható és kiszámítható & 5 & 5 & 5 & 4 & 4 & 5 & 4 & 3 & 4 & 5 \\
\hline Alacsony kockázat & 1 & 3 & 1 & 5 & 5 & 3 & 4 & 4 & 4 & 5 \\
\hline Összesített & 15 & 28 & 19 & 34 & 33 & 24 & 25 & 23 & 28 & 26 \\
\hline
\end{tabular}


- Mindezzel összefüggésben csak olyan innovációk lesznek versenyképesek, amelyek nemcsak a tradicionális müszaki megoldásokra (tech-innovációk), de az egész termékpályát átölelö innovációkra - tehát szervezési, szervezeti, üzleti, piaci, szabályozási stb. innovációkra - is fókuszálnak (non-tech innovációk). Alapvetően ez utóbbiakon múlik a versenyképesség, mert a technikai megoldások önmagukban még kevesek.

- Sőt a projektek kapcsán figyelmet kell fordítani a hightech (világszínvonalú) innovációk mellett a low-tech (helyi feltételekhez illeszkedö) innovációkra is. Gyakori eset, hogy a hightech innováció az egyik helyen müködik, a másikon csődöt mond - például kvalifikált munkaerő hiánya vagy infrastrukturális, intézményrendszerbeli problémák miatt.

\section{Fenntarthatósági prioritás}

„Környezeti, gazdasági és társadalmi indikátoraink egyértelmüen azt üzenik, hogy jelenlegi müködési modellünk fenntarthatatlan.” (Ban Ki Mun, 2016)

Ennek előtérbe kerülését az alábbi főbb szempontok indokolják:

- Harmonizálniuk kell a gazdasági, társadalmi és ökológiai követelmények$n e k$, ami felelős és tájékozott szereplöket (döntéshozókat és megvalósítókat) feltételez.

- Internalizálni kell az externáliákat az üzleti modellekbe, ami röviden anynyit jelent, hogy a projekteket LCA alapon (Life Cycle Analysis, azaz teljes életciklusukra vetítve) kell minősíteni. Ennek összegzése a projekt egyfajta ökológiai lábnyoma, amely magában foglalja a környezeti terhelés minden formáját, beleértve az energiamérleget is. Például ezen az alapon az elektromos gépkocsi csak akkor kedvezőbb a fosszilis energiahordozóval müködőnél, ha az áramot megújuló (és nem fosszilis) energiaforrással állítjuk elö.

- A bioenergetikai döntéseket az egyre határozottabban körvonalazódó új, komplex ágazat, a bioökonómia (a biomassza előállításához, feldolgozásához és hasznosításához kapcsolódó valamennyi termelő és szolgáltató tevékenység) keretébe kell illeszteni. Ezen túlmenően pedig a rendelkezésre álló biomassza maximális hozzáadott értékü hasznosítása, valamint a „zéró hulladék" elv megvalósítása mellett a 2. ábrán látható nemzetstratégiai prioritások teljesülése is minősítési szempontként szolgál.

\section{Hosszú távú kitekintés}

„Sokan vagyunk rá képesek, hogy felfogjuk az innováció rendkívüli fontosságát. Ez az egyetlen épeszủ stratégia, hogy túléljük gyalázatosan müködő gazdaságunkat." (Gary Hamel, 2013) 


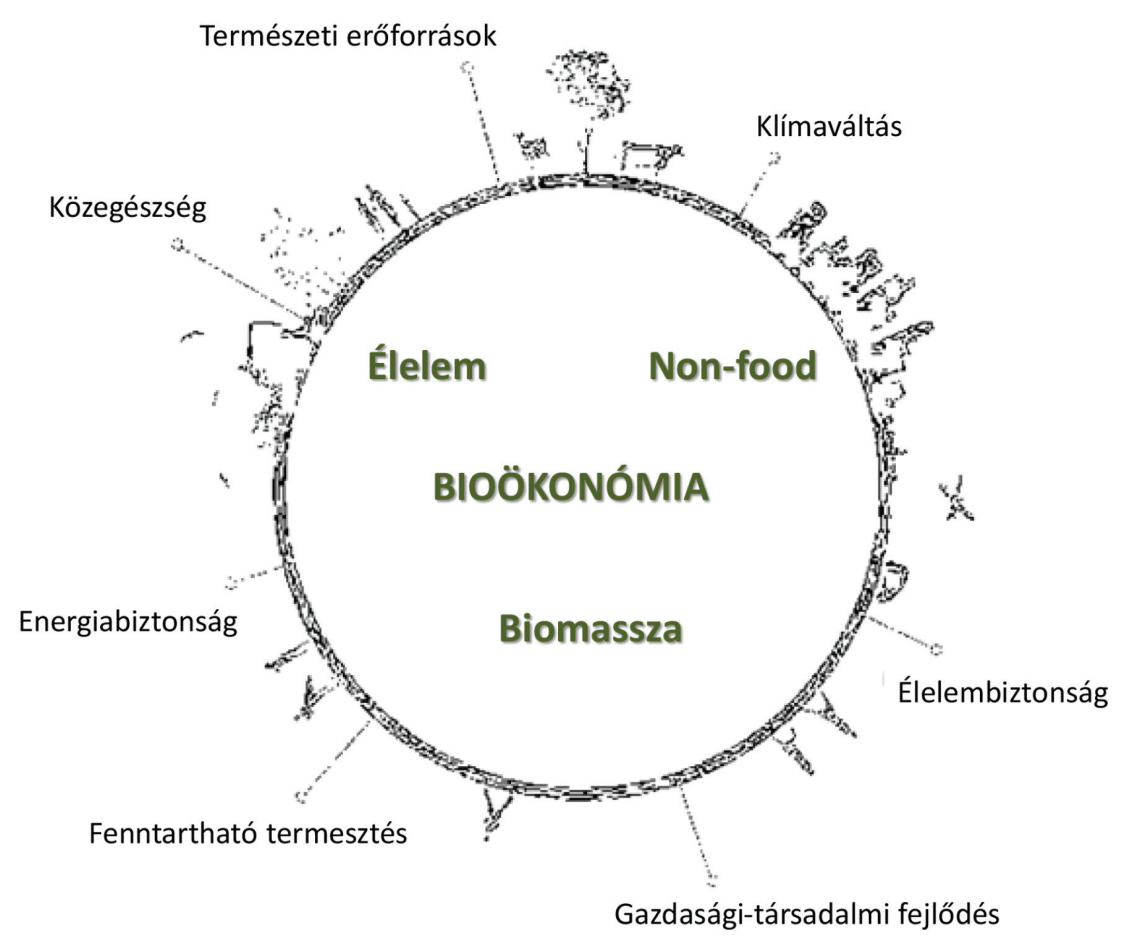

2. ábra. A bioenergetika a bioökonómia alágazata (saját szerkesztés)

Bármennyire kockázatosnak látszik, a bioenergetikai (és értelemszerủen általában az energetikai fejlesztési, beruházási) döntéseknél nem mellőzhetők a flexibilis alkalmazkodás szempontjai (az ún. kontingenciatervezés). Kritériumok:

- Exponenciálisan gyorsuló a technológiai fejlödés a megújuló energiaforrások területén, mert a magas profit reményében hatalmas tőkemennyiség áramlik az ágazatba (főként a nap- és a szélenergiával kapcsolatos fejlesztésekbe). Ez belátható távon a korábban vártnál jóval jelentősebb mértékben csökkenti a fosszilis energiaforrások arányát az energiamixben. A bioenergiának ebben a versenyben kell megtalálnia a helyét.

- Nemcsak a technológiai fejlődés, de a társadalmi, gazdasági és a szabályozási változások is gyorsulnak, irányuk eredője pedig az általános és globális „zöldülés”, amely alkalmazkodásra kényszeríti a bioenergetikai ágazat szereplöit is.

- Különösen jelentős változás a gazdaság és a társadalom digitalizációja (4.0 ipari forradalom), amelynek kapcsán újra napirendre kerülnek azok a törekvések, amelyek európai szinten integrálni kívánják az osztott (decentralizált) energiahálózatot, lásd a Super Smart Grid (SSG, szuper intelligens hálózat) megvalósítását. Ebben az integrálás (összehangolás) csak egyik elem a sok 


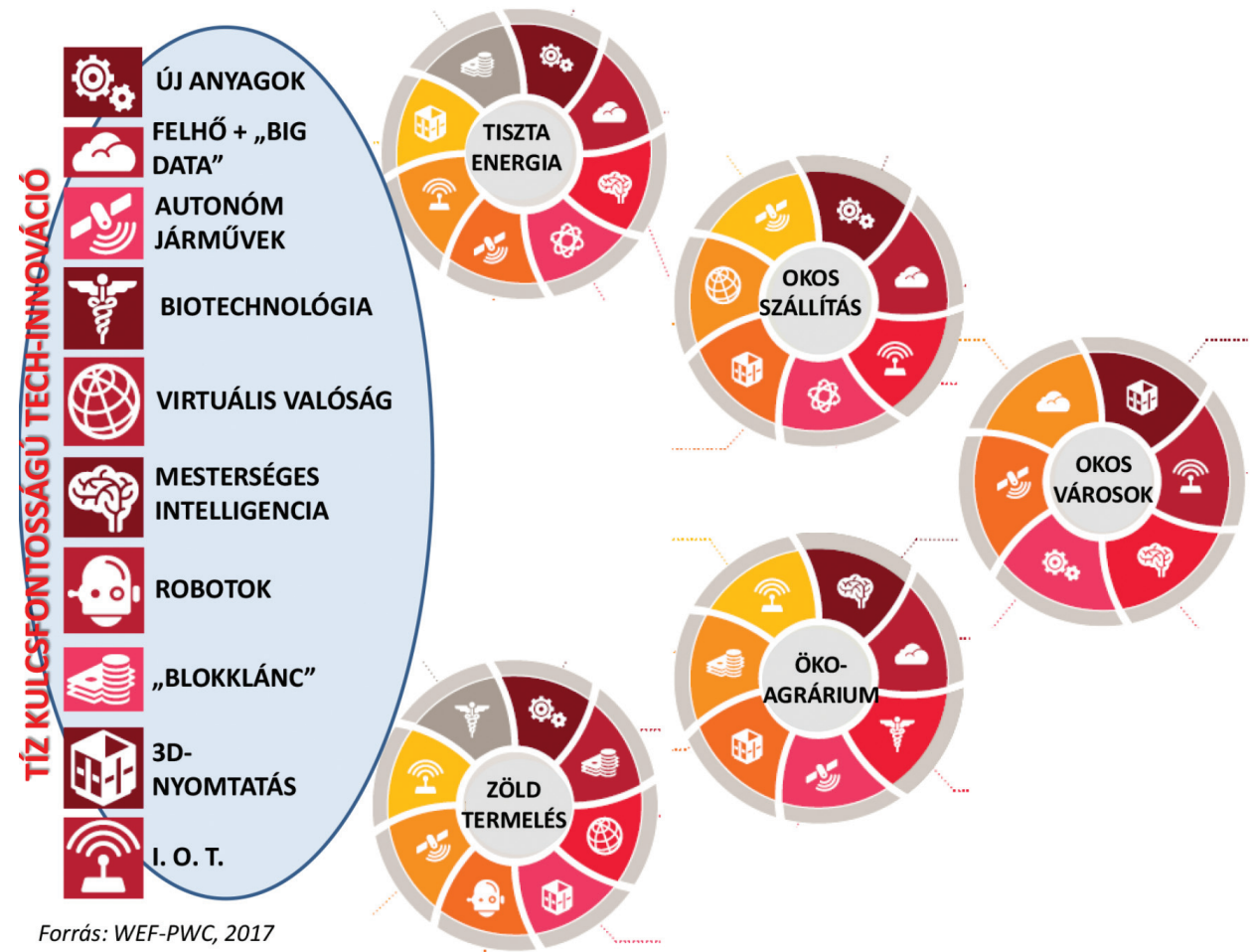

3. ábra. A 4.0 ipari forradalom átformálja a bioenergetikát is (saját szerkesztés)

közül. Amint a 3. ábra mutatja, tíz olyan kulcsfontosságú innováció öszszefonódása várható, amely alapjaiban formálná át az energetikai (egyben a gazdasági-társadalmi) paradigmát. (Az I. O. T. jelentése: Internet of Things, azaz [hálózatba kapcsolt, okos] eszközök internete.)

- Ebben a „szép új világban” minden olyan jelentős volumenű energetikai projekt, amely hosszú távon kényszerpályát képezhet (lehetetlenné teszi a rugalmas alkalmazkodási, váltási lehetőségeket) komoly stratégiai fenyegetés mind makro-, mind mikroszinten. Ez érvényes a bioenergetikai beruházásokra éppúgy, mint az atomenergiára.

\section{Vertikális szinkron}

„A globalizáció korában mindenki a globális társadalom tagja, csak fogalmunk nincs, hogy ezt hogyan kellene müködtetni.” (Ruchir Shama, 2015)

A bioenergetikai termékpályák (alapanyag előállítása, begyüjtése, logisztika, feldolgozás, energetikai hasznosítás, melléktermék kezelése, hasznosítása, ener- 
giarendszer, szállítás, fogyasztás) kialakítása, a sokféle szereplő ún. vertikális összehangolása a termékpálya mentén sokkal bonyolultabb, mint az egyszerü megújulóknál (nap- és szélenergia). A kudarcsztorik többnyire ebből fakadnak. Fö kérdések:

- A vertikális összhangot mikro- (lokális), makro- és EU- (globális) szinten is meg kell teremteni, mert ,aki kimarad, az lemarad”.

- Éppen a lokális feltételek sokszínúsége miatt a sokáig üdvözítőnek tekintett „best practice” (legjobb gyakorlat) megoldással sokra nem megyünk - innovatív módon ki kell alakítani a helyi szinten legjobb, azaz a helyi ,jó gyakorlatokat" (good practices). Ami nem azt jelenti, hogy a legjobb gyakorlatot nem kell ismerni, csak az adaptáció nem mellőzhető.

- A realitások talaján állva kell tisztázni az adott helyen ténylegesen rendelkezésre álló biomassza-potenciált.

2. táblázat. A hazai biomassza-potenciál eltérő megközelítései

\begin{tabular}{|l|c|}
\hline \multicolumn{1}{|c|}{ Bioenergetikai potenciál fajtája } & Nagysága (PJ / év; \%) \\
\hline Elméleti bioenergetikai potenciál & $\mathbf{1 1 0 0 ~ P J / e ́ v ~}=100 \%$ \\
\hline Strukturális potenciál & $420 \mathrm{PJ} / \mathrm{e} v=38 \%$ \\
\hline Konverziós potenciál & $386 \mathrm{PJ} / \mathrm{e} v=35 \%$ \\
Gazdasági potenciál & $260 \mathrm{PJ} / \mathrm{e} v=24 \%$ \\
\hline Fenntartható potenciál & $\mathbf{1 8 6}$ PJ/év $=17 \%$ \\
\hline
\end{tabular}

Szakterületek közötti szinkron

„Semmi sem fenyeget jobban egy rugalmatlan rendszert, mint a szakmai alapú gondolkodás.” (Derek Kassem, 2011)

Miután az energiapolitikában jó ideje a politikai szempontok dominálnak, sokak számára meglepő eredményekre jutnánk, ha a szakmai megfontolások kerülnének túlsúlyba. Azaz:

- Egyensúlyt (kompromisszumot) kell teremteni a tudományos, szakmai és politikai prioritások között, a különféle (ellen)érdekủ lobbik „hitvitákká” fajult küzdelmét csak ezen az alapon lehet eldönteni. Az energiaszektor átpolitizáltságát jól mutatják a legújabb nemzetközi elemzések, amelyek alapján a fosszilis energiahordozók (beleértve az atomenergiát is) évente globálisan 775-1000 milliárd USD (!) nagyságú kormányzati támogatást élveznek, amelynek csak töredéke a megújulók, ezen belül a biomasszából elöállított energiahordozók támogatása. És ebben még nem szerepelnek azok az ex- 
ternális társadalmi költségek, amelyeket így vagy úgy, de „megfizetünk”: a környezeti károk, egészségügyi problémák, fegyveres konfliktusok kiadásai. Ez utóbbiak kalkulált globális többletköltsége évente kb. 5300 milliárd USD (Coady et al., 2015).

- Az ún. energia-trilemma feloldását kell megcélozni, mert ennek bármelyik eleme (energiabiztonság, megújuló energiaforrások bevonása, lehető legszélesebb körủ energia-hozzáférés biztosítása) kerül kiemelésre, azaz háttérbe vagy elötérbe, az nemzetstratégiai tévedéshez vezet.

- A bioenergetikában érintett szereplők szoros együttmüködése elkerülhetetlen, ehhez viszont tudásközpontok, tudáshálózatok, tudásszolgáltatók kiépítése és müködtetése szükséges. „Egyedül nem megy...”

- Minden szintü döntéshozatalnál számüzendö a bulvárszintü megközelités, mert ez a szűkös társadalmi, gazdasági és természeti erőforrások eszement pazarlásához vezet. Korrekt, szakmailag megalapozott, komplex információkra van szükség.

\section{ÖSSZEFOGLALÁS}

Hazai használatra az elmondottak alapján érdemes megfogalmazni bizonyos bioenergetikai „ökölszabályokat”, amelyeket, ha érvényesítünk a makro-, illetve projektszintü döntéseknél, akkor nem követhetünk el nagy hibát.

Rögzítsük a támogatási prioritások sorrendjét:

1. Csak auditált projekteket (komplex audit) támogassunk, illetve engedélyezzünk.

2. Fő szempont legyen a melléktermékek, biohulladék hasznosítása.

3. Csak ezt követően legyen lehetőség fás/lágy szárú energianövények nem használt földeken fötermékként történő termesztésére.

4. Legvégső esetben jöhet szóba energianövények termesztése más hasznosítási céllal versengő földeken.

Gazdaságosság megítélése:

- Más a jelen, más a jövő - csak hosszú távú gazdasági-technológiai előrejelzésekhez és globális trendekhez illeszkedő technológiákra alapozzunk.

- Érvényesüljön a „termelj és fogyassz helyben!” elv a bioenergetikai fejlesztési projekteknél.

- Kiemelt prioritás legyen az energia- és emissziós mérleg, hatékonyság, üzemi méretek és a fenntarthatóság körültekintő értékelése.

- Tiszta képet kell alkotni a teljes energiaszektoron belül valamennyi energiahordozó valós költségeiről (különféle támogatások nélkül és beszámítva a tényleges externáliákat). 
Gyorsuló technológiai fejlődés:

- Rugalmas (moduláris) megoldásokra fókuszálni.

- Komplex rendszerekre törekedni (a körkörös gazdaság szempontjaival szinkronban).

- Fontos követelmény a hálózatos szerveződés, mégpedig alulról - a hazai szereplők integrációi, hálózatai.

- Mindig szükség van helyi adaptációkra, ehhez pedig elérhető tudásközpontokra és tudásszolgáltatókra.

Ezekből is kiindulva született meg a 2017. április 6-i ankét állásfoglalása a biomassza energia célú hasznosításának javasolt hazai prioritásairól.

\section{IRODALOM}

Bocca, R. et al. (2017): Game Changers in the Energy System Emerging Themes Reshaping the Energy Landscape. World Economic Forum - McKinsey Company, "White Paper", REF 050117, 1-20. http://www3.weforum.org/docs/WEF_Game_Changers_in_the_Energy_System.pdf

Coady, D. et al. (2015): How Large Are Global Energy Subsidies? IMF Working Paper - WP 15/105, 1-42. https://www.imf.org/external/pubs/ft/wp/2015/wp15105.pdf

Dinya L. (2010): Biomassza-alapú energiatermelés és fenntartható energiagazdálkodás. Magyar Tudomány, 171, 8, 912-925. http://www.matud.iif.hu/2010/08/03.htm

Hawksworth, J. et al. (2017): The Long View-How Will the Global Economic Order Change by 2050? London, UK: WEF - PWC, 1-72. https://www.pwc.com/gx/en/world-2050/assets/pwcworld-in-2050-summary-report-feb-2017.pdf

International Energy Agency (2016): Key World Energy Statistics - 2015. Paris: OECD / IEA, 1-81. https://webstore.iea.org/key-world-energy-statistics-2017

Paulos, B. (2017): On Biofuels, Part 3. The Future of Bioenergy. https://energytransition. org/2017/01/part-three-the-future-of-bioenergy/, letöltés: 2017. 03. 18.

Pelkmans, L. (2016): Results of a Global Survey on International Biomass Trade for Energy - Opportunities, Risks and Policy Options. European Biomass Conference \& Exhibition, Amsterdam, 8 June 2016, 1-9. https://uhdspace.uhasselt.be/dspace/handle/1942/21760

Schiffer, H.-W. et al. (2016): World Energy Resources - 2016. World Energy Council, London, 1-1028. https://www.worldenergy.org/wp-content/uploads/2016/10/World-Energy-ResourcesFull-report-2016.10.03.pdf 